\title{
Do Vocabulary Learning Strategies Correlate to Reading Comprehension?
}

\author{
Muhaimin \\ Departemen Pendidikan Bahasa dan Sastra \\ Universitas Negeri Surabaya \\ Surabaya, Indonesia \\ muhaiminmuhaimin@mhs.unesa.ac.id
}

\author{
Suharsono \\ Departemen Pendidikan Bahasa dan Sastra \\ Universitas Negeri Surabaya \\ Surabaya, Indonesia \\ suharsono@unesa.ac.id
}

\author{
Ahmad Munir \\ Departemen Pendidikan Bahasa dan Sastra \\ Pascasarjana Universitas Negeri Surabaya \\ Surabaya, Indonesia \\ ahmadmunir@unesa.ac.id
}

\begin{abstract}
This paper aims to analyze correlation of vocabulary learning strategies (VLSs) and reading comprehension. The study was conducted with a quantitative approach and employed thirty students of senior high school as the participants. The data were collected through questionnaire and statistically analyzed using SPSS. The results of the research show that the students employed five strategy categories in which cognitive strategies as the most used strategies and had strong positive correlation with reading comprehension, while four strategy categories; metacognitive, determination, memory, and social were moderate correlation. Based on this analysis, it can be concluded that there is a significant positive relationship between vocabulary learning strategies and reading comprehension. It can be said that the more frequently the students employed VLSs, the higher score of reading comprehension they achieved. The present research recommends that English teachers should give appropriate strategies to the students in order to have skills to acquire the words' meaning when they encounter reading texts.
\end{abstract}

Keywords- vocabulary learning strategies (VLS), strategy, reading comprehension

\section{INTRODUCTION}

The main goal of vocabulary learning strategies (VLS) is to assist students to comprehend text. Dozens of studies carried out have documented a strong relationship between vocabulary knowledge and comprehension, finding that vocabulary knowledge determines one's reading comprehension $[1,2]$.

The importance of strategies for determining the meaning of unknown words leads an idea that students should be equipped by several strategies to learn vocabulary as well as to acquire unfamiliar words to support text comprehension. That is, students are more likely to recognize the meanings of a majority of the words in a text and are likely to be better text comprehenders when they know more vocabulary knowledge [3].
Those strategies hopefully enable the students to understand the concepts of unfamiliar words, to gain a greater number of words, and to use them successfully for communicative purposes is the aim of vocabulary teaching $[4,5]$. Thus, mastery of each of the language skills, both receptive (listening and reading) and productive (speaking and writing) is supported by good vocabulary mastery.

The relationship between vocabulary and language skill is described by a linguist, David Wilkins cited by Thornbury [6], about how the importance of vocabulary learning by saying "Without grammar very little can be conveyed, without vocabulary nothing can be conveyed." In accordance with this, Hunt and Beglar [7] claim that vocabulary is the heart of language comprehension and language use since the role of vocabulary in communication is so important that it encourages learners to employ their efforts to recognize some unknown words.

To communicate effectively, not only English as Second language (ESL) learners but also English as Foreign Language (EFL) learners require the number of vocabulary. Acquiring the large number of words becomes people's need when they have to read or write. However, in some cases, learners may face some difficulties and in learning second and foreign language, learners can also run into troubles when making progress in gaining proficiency. As a result, they may require some techniques, activities, or actions to use in learning second or foreign language [6]. These strategies are quite significant to help learners acquire an amount of vocabularies in ESL and EFL as well.

Learning vocabulary becomes extremely urgent for those who need to master the number of vocabulary because unknown word that learners come across in the text may negatively influence their reading comprehension [8]. They, therefore, require some techniques and strategies in order to master vocabulary more effectively and faster. The strategy that 
learners take to do some tasks to master vocabulary can be considered as vocabulary learning strategies.

Vocabulary learning strategies (VLS) are under umbrella of learning strategies which require particular strategies as well. VLS have drawn researchers' interests to investigate, which lead them propose various concepts of VLS. Cameron [9], for example, defines VLSs as "actions that learners take to help themselves understand and remember vocabulary". In this definition, Cameron infers that applying some actions or steps can assist learners in acquiring a large vocabulary. In line with this idea, Schmitt [10] claims that the actions and learners' strategic behavior has an effect in mastering new vocabulary because one's self-regulation of learning leads to more involvement with learning process. However, McCarthy [11] adds that few learners are equally good at maximizing their strategic resources. It means every learner has different strategies and, of course, may achieve the goals differently [12]. In this line of argument, it is insightful to reckon research conducted by Moir and Nation [13] also conclude that all the learners in this study believe vocabulary to be important, and they invest a lot of time and effort in learning vocabulary, however, only few learners can be effective ones.

Choosing which strategies will be used by the learners is personal preference. It means different person has different choice of strategies based on personal experiences and condition. Some factors influencing the learners' preferences in these strategies can be gender [14-16], proficiency level [17-19], family background [20,21], and other factors.

In sum, VLS can be viewed as a sequence of actions, efforts, and behavior taken by the learner to master a number of new vocabularies by maximizing vocabulary resources. These actions and efforts can regulate to lead to more involvement with learning process. By applying some strategies, the learners can learn vocabulary not only in classroom during teaching learning process but also outside classroom. The learners can independently and autonomously regulate themselves in learning vocabulary because some efforts used by the learners can vary from one person to another based on need and condition.

Vocabulary learning strategies (VLSs) have been worldwide issues in English language teaching and have drawn extensive attention from scholars in the last few decades. It is showed by dozens of studies which have been carried out to get deep insight into many aspects of vocabulary learning strategies. The study conducted by Kafipour, et al. [22], for example, investigated the type of vocabulary learning strategies used by Malaysian ESL students majoring at Teaching English as a Second Language (TESL) who show that the respondents prefer some strategies such as the learning a word through reading, the use of monolingual dictionary, the use of various English language media, and applying new English word in their daily conversation. However, this research has not revealed whether the strategies used by the students correlate to English skill or not. Therefore, it is difficult to identify how students' strategies donate English skills such as reading.

Other study of the use of English vocabulary learning strategies conducted by $\mathrm{Na}$ [16] who explored gender differences in students' choice of English vocabulary learning strategies in Chinese high schools. There are distinctive differences in the use of vocabulary learning strategies for different genders. Social strategies are more likely to apply by male students than female students, while metacognitive and cognitive strategies are more frequently used by female students than male ones. Although this survey is expected to contribute to the further research in this area by briefly analyzing gender differences and the use of English vocabulary learning strategies, not all aspects this research has been considered such as whether students' strategies correlate to English skill or not. This is important aspect in the research to see a relation of the students' strategies of vocabulary learning and English skills such as reading.

In Indonesian context, Subekti and Lawson [23] investigated vocabulary acquisition strategies of Indonesian postgraduate students' learning through reading. The 25 participants (ten male and fifteen female) were between 28 and 40 years old and studied at the postgraduate level at a university in South Australia. The students provided demographic information about gender, length of time in Australia, English Language (IELTS) scores received before entering the university. The results of the research show that reading can be used as a means to acquire the meanings of new words. The postgraduate L2 learners of English who participated in this study were active strategy users, even though most of their strategy use excluded substantial degrees of elaboration. The students might remember having encountered words previously even though they could not recall the meanings of some of those words.

The research observed the strategies procedures to find the meanings when they encounter unknown English words and frequency of the strategies use. It can conclude that reading has an important role in learning since it is as a tool to acquire new words. However, no research on VLS has been reported to explore the correlation of the strategies of finding unknown words and reading.

Based on the above discussion, several reasons guide the current study. First, the number of studies on the statistic relationship between certain strategies of learning vocabulary and reading comprehension is fairly limited in Indonesian context. Thus, it seems necessary to reveal whether there is a relationship between VLSs and reading comprehension. Second, the findings obtained from the prior studies have not reached the senior high school students 'case in Indonesian context. To conclude, it is evident that research is strongly necessary to explore whether there exists a relationship between VLSs and reading comprehension among Islamic senior high school students.

\section{METHODS}

The participants in the study were thirty students who learn English as foreign language at a private Islamic senior high school in Jepara, central Java. The sample group were 10th grade students and taken by using random sampling technique.

Two research instruments were employed to collect data. First, questionnaire of vocabulary learning strategies (QVLS) which consisted of 36 items was aimed to interrogate the participants' strategies of learning English vocabulary when they encountered reading texts. The scale from one to five $(1=$ 
never, $2=$ seldom, $3=$ sometimes, $4=$ often, $5=$ always) were included in the questionnaire. The QVLS were modified from Schmitt's taxonomy (2001) adapted from Bennett [24]. The adaptation steps were the translation process, simplification, moderation, a pilot study, and the validation of the QVLS. To validate, QVLS were tried out to thirty students (not the participants) who have the same level as the participants. Then, by using SPSS, the reliability coefficient of the QVLS when being tried out was found 0.087 in Cronbach Alpha indicating a high level reliability. To complete the questionnaire, the participants were given one hour during class time, afterwards being told that the results of this task would have no influence on their marks. The participants were asked to read the questionnaire and only then select those strategies that they used in accordance with their opinion. The participants were also allowed to ask questions if they did not understand the scale items. Second instrument was reading test adapted from national examination which consists of 25 questions. The questions contain main idea, inference, supporting idea, and vocabulary in context. The reliability coefficient of reading texts was found 0 . 863 while difficulty level was found 0.6 representing moderate test which indicates that reading texts were reliable to be tested.

\section{RESULTS AND DISCUSSIONS}

The findings present the statistical analyses of the relationship between vocabulary learning strategies and students' reading comprehension. Each strategy of five categories has the relationship with reading proficiency. The results of the data are intended to answer the research question.

Product moment analysis is employed to reveal significant relationship between vocabulary learning strategies and students' reading comprehension. The significant positive correlations were found between five categories of the strategies and reading comprehension, as presented in Table 1.

TABLE I. CORRELATIONS OF READING COMPRHENSION AND VLS

\begin{tabular}{|c|c|c|c|c|c|c|}
\hline & $\begin{array}{c}\text { Score of } \\
\text { Reading } \\
\text { Compreh } \\
\text { ension } \\
\end{array}$ & $\begin{array}{l}\text { Determinat- } \\
\text { ion Strategy }\end{array}$ & $\begin{array}{l}\text { Social } \\
\text { Strategy }\end{array}$ & $\begin{array}{l}\text { Memory } \\
\text { Strategy }\end{array}$ & $\begin{array}{c}\text { Cognitive } \\
\text { Strategy }\end{array}$ & $\begin{array}{c}\text { Metacognitive } \\
\text { Strategy }\end{array}$ \\
\hline \multirow{2}{*}{\multicolumn{2}{|c|}{$\begin{array}{l}\text { Score of1 } \\
\text { Reading } \\
\text { Comprehe } \\
\text { nsion }\end{array}$}} & $.549^{* *}$ & $.425^{*}$ & $.533^{* *}$ & $.662^{* *}$ & $.593^{* *}$ \\
\hline & & .002 & .019 & .002 & .000 & .001 \\
\hline \multirow{2}{*}{\multicolumn{2}{|c|}{$\begin{array}{l}\text { Determinat. } 549^{* *} \\
\text { ion } \\
\text { Strategies } .002 \\
\end{array}$}} & 1 & .185 & .279 & $.393^{*}$ & $.581^{* *}$ \\
\hline & & & .328 & .136 & .032 & .001 \\
\hline \multirow{2}{*}{$\begin{array}{l}\text { Social } \\
\text { Strategies }\end{array}$} & $.425^{*}$ & .185 & 1 & .268 & $.553^{* *}$ & $.366^{*}$ \\
\hline & .019 & .328 & & .152 & .002 & .047 \\
\hline \multirow{2}{*}{$\begin{array}{l}\text { Memory } \\
\text { Strategies }\end{array}$} & $.533^{* *}$ & .279 & .268 & 1 & $.486^{* *}$ & $.395^{*}$ \\
\hline & .002 & .136 & .152 & & .007 & .031 \\
\hline \multirow{2}{*}{$\begin{array}{l}\text { Cognitive } \\
\text { Strategies }\end{array}$} & $.662^{* *}$ & $.393^{*}$ & $.553^{* *}$ & $.486^{* *}$ & 1 & $.501^{* *}$ \\
\hline & .000 & .032 & .002 & .007 & & .005 \\
\hline \multicolumn{2}{|c|}{$\begin{array}{l}\text { Metacogniti } .593^{* *} \\
\text { ve Strategies.001 }\end{array}$} & $\begin{array}{l}.581^{* *} \\
.001\end{array}$ & $.366^{*}$ & $.395^{*}$ & $.501^{* *}$ & 1 \\
\hline
\end{tabular}

One of the strategy categories, cognitive, is classified into strong correlation while the rest, metacognitive, determination, memory, social, are moderate correlation. Significant positive correlation between reading comprehension and cognitive strategies was the strongest $(\mathrm{r}=.662, p=.000)$, whereas the least significant association was between reading comprehension and social strategy $(\mathrm{r}=.425, p=.019)$ pointing to moderate correlation.

It is interesting here to note that cognitive strategies such as grouping words, taking notes or highlighting new words in class, making lists of new words, using flash cards to record new words, remembering the word using its word form, repeating the words aloud many times, saying the new words aloud and making one own definition, and putting English labels on physical objects strongly have correlate to reading comprehension.

Meanwhile, the strength of significant positive correlations between reading comprehension and the other three strategies were varied. For example, the correlation between reading comprehension and metacognitive strategies was found moderate $(\mathrm{r}=.593, p=.001)$, while reading comprehension and determination strategies was reported $(\mathrm{r}=.549, p=.002)$. Furthermore, the significant positive correlations between reading comprehension and memory strategies was also categorized as moderate $(\mathrm{r}=.533, p=.002)$. Although the significant positive correlations between reading comprehension and the three strategy categories were various ranks, they all point to moderate correlation.

The analysis of relationship (using Pearson correlation) between overall VLS and reading comprehension indicates that the more frequently the students employ several of VLS i.e. cognitive, metacognitive, determination, memory, and social strategies, the higher the score of reading comprehension they achieve. This also shows that students' proficiency correlates to the use of VLS used by the students. The more proficient the students are, the more the students employ those strategy categories.

Of the five strategy categories, cognitive category was classified into positive strong correlation but the others were categorized as positive moderate correlation as shown in Table 2. In the study, the least significant association occurs between reading comprehension and social strategy, although it still shows moderate correlation. It means that asking the teacher to give the definition of a sentence, asking classmates for the meaning, studying the word with classmates, asking the teacher to check the definition, and talking with native speakers were several strategies reported as the least significant association with reading comprehension. It is also important to note the strength of significant positive correlation of reading comprehension of the other three strategies i.e. metacognitive, determination, and memory strategies was also moderate correlation.

Additionally, even though determination and memory shared the same score of significance level, those strategy categories had the different strength of correlation. It means the students employed determination and memory in the same level of use when encountering unfamiliar words in English texts. Thus, both categories were placed in the dissimilar rank. 
The correlations between reading comprehension and overall strategies of VLSs indicate the statically significant strong. Those strategies of VLSs are really required to understand L2 texts, as stated by McCarthy [11] who claims "No matter how well the student learns grammar, no matter how successfully the sounds of L2 are mastered, without words to express a wider range of meanings, communication in an L2 just cannot happen in any meaningful way".

Even though, in the current study, the score of significance ( $p$-value) is varied, the results of the study show the strong and moderate correlation; one strong correlation exists between reading comprehension and cognitive strategies, while four moderate correlations lie between reading comprehension and strategy categories; metacognitive, determination, social, and memory. As put forward in research conducted by Nation [25], vocabulary knowledge as the result of VLS is closely related with reading comprehension each other; reading can contribute to vocabulary growth while vocabulary knowledge can help and determine successful reading. Meanwhile, as stated by Nassaji [8] that according to several studies on foreign language reading comprehension, many unknown word that learners encounter in the text may negatively disrupt their reading comprehension.

Positive significant correlation between reading comprehension and cognitive strategies was the strongest among five strategy categories. This is in agreement with the study conducted by $\mathrm{Gu}$ and Johnson [26] who found that cognitive strategies concerning note-taking strategies were positively correlated with reading tests, while using linguistic clues like grammatical structures of a sentence could guess the meaning of a word.

However, several strategies of metacognitive category based on Schmitt's taxonomy; using English media like computer or via mobile phone as regulating one's self, more greatly correlate to reading comprehension compared with a strategy in cognitive using flashcard as quoted by Başoğlu and Akdemİr [27], Azabdaftari and Mozaheb [28]; and Lu [29]. Thus, this research places metacognitive strategies as the second rank of the strength.

In the study of metacognitive strategies, research conducted by Moir and Nation [13] concluded that autonomy and metacognition has significant role in learning vocabulary if language learners want to be successful. In order to learn vocabulary effectively, they emphasized, the students must have the ability or skill to do the learning, the attitude or willingness to take control of their own learning, and they must develop a reflective awareness of their own approaches to learning in order to learn vocabulary effectively. With the number of vocabulary, the students are expected to conquer or master more unfamiliar words or low frequent words in reading texts. It is likely possible to reveal a lot of ideas in reading comprehension.

Some studies, as quoted earlier, show that the learners with high proficiency tend to use metacognitive strategies such as manage, regulate, and evaluate themselves in learning vocabulary especially when they are faced a reading. However, this does not happen in the current research because the students may rely on how to manipulate their cognition in order to comprehend reading texts. To acquire a number of the unfamiliar words, a student can employ cognitive aspect such as; noticing words, highlighting foreign words, keep vocabulary in the notebook.

The significant positive correlation shows that it is likely the students who use VLSs more frequently are more capable of achieving the higher the grade of reading comprehension. It also indicates that the more proficient a learner is, the more frequently the learner use social, cognitive, metacognitive, determination, and memory strategies. The results of the study partially confirmed the findings of Rezvani and Jabbari [30] who revealed that VLSs have a positive effect on improving learners' reading comprehension.

\section{CONCLUSIONS}

By exploring the relationship of VLS and reading comprehension, the present research comes to the following conclusion that the correlation of the use of VLSs and reading comprehension proves different level of strength. The relationship between cognitive strategies and reading comprehension was strong positive correlation. It shows that the more the students employ cognitive strategies the higher score of reading comprehension they achieved. Meanwhile, four other strategy categories; determination, social, memory, and metacognitive had moderate positive relationship.

Future studies involving more students with different characteristics and contexts are needed to reveal the relationship between the use of VLSs and reading comprehension. Therefore, a broader coverage of sources of data involving students with a different range of grade, age, gender, and area may also become an interesting focus of the next research studies and imperative for future investigations.

\section{ACKNOWLEDGMENTS}

This manuscript is a partial result of the research under title Investigating Vocabulary Learning Strategies used by EFL Learners in Reading Comprehension. The authors are very grateful to anyone who provides insightful comments and feedback. All lack of clarity and omissions remain entirely the authors' responsibility.

\section{REFERENCES}

[1] M. Sénéchal, G. Ouellette, and D. Rodney, " The Misunderstood Giant: On the Predictive Role of Early Vocabulary to Future Reading," in Handbook of Early Literacy Research. vol. 2, D. K. Dickinson and S. B. Neuman, Eds., ed New York: Guilford, 2006, pp. 173-182.

[2] J. Ricketts, K. Nation, and D. V. M. Bishop, " Vocabulary is Important for Some, but Not All Reading Skills," Scientific Studies of Reading a Foreign Language, vol. 11, pp. 235-257., 2007.

[3] T. S. Wright and G. N. Cervetti, "A Systematic Review of the Research on Vocabulary Instruction That Impacts Text Comprehension," Reading Research Quarterly, vol. 0, pp. 1-24, 2016.

[4] B. Y. Cahyono and U. Widiati, "The Teaching of EFL Vocabulary in The Indonesian Context: The State of The Art " TEFLIN Journal vol. 19, pp. $1-17,2008$

[5] B. L. Leaver, M. Ehrman, and B. Shekhtman, Achieving Success in Second Language Acquisition. Cambridge: Cambridge University Press, 2005.

[6] S. Thornbury, How To Teach Vocabulary. Pearson Education Limited Longman UK, 2002.

[7] A. Hunt and D. Beglar, "A Framework for Developing EFL Reading Vocabulary," Reading in a Foreign Language, vol. 17, pp. 23-59, 2005. 
[8] H. Nassaji, "L2 Vocabulary Learning From Context: Strategies, Knowledge Sources, and Their Relationship With Success in L2 Lexical Inferencing," TESOL Quarterly vol. 37, pp. 645-670, 2003.

[9] L. Cameron, Teaching Languages to Young Learners. Cambridge Cambridge University Press, 2001.

[10] N. Schmitt, Researching Vocabulary: A Vocabulary Research Manual. New York: Palgrave Macmillan, 2010.

[11] M. McCarthy, Vocabulary Oxford: Oxford University Press 1990.

[12] N. Schmitt, " Key Issues in Teaching and Learning Vocabulary " in Insights into Non-native Vocabulary Teaching and Learning, R. ChacónBeltrán, C. Abello-Contesse, M. d. Mar, and Torreblanca-López, Eds., ed Multilingual Matters: Bristol 2010.

[13] J. Moir and P. Nation, " Vocabulary and Good Language Learners," in Lessons from Good Language Learners, C. Griffiths, Ed., ed Cambridge: Cambridge University Press 2008

[14] R. M. J. Catalan, "Sex Differences in L2 Vocabulary Learning Strategies," International Journal of Applied Linguistics, vol. 13, pp. 54-77, 2003.

[15] S. Lee, "Vocabulary Learning Strategies of Korean University Students: Strategy Use, Vocabulary Size, and Gender " English Teaching vol. 62, pp. 149-169, 2007.

[16] W. Na, "Gender Differences in the Use of English Vocabulary Learning Strategies in Chinese Senior High Schools," Studies in Literature and Language, vol. 12, pp. 58-62, 2016.

[17] S. Askani, "Vocabulary Learning Strategies of Iranian High School Language Learners " International Journal of Language Learning and Applied Linguistics World vol. 7, pp. 248 --271, 2014.

[18] T. Komol and W. Sripetpun, "Vocabulary Learning Strategies Employed by Undergraduate Students and its Relationship to their Vocabulary Knowledge " presented at the The 3rd International Conference on Humanities and Social Sciences Prince of Songkla University 2011.

[19] C. Vichet, "Vocabulary Learning Strategies (VLS) of High-Achieving Indonesian EFL Undergraduate Students " Master Degree, English Education Department, Universitas Pendidikan Indonesia, Bandung, 2014.

[20] T. Ahour and P. Salamzadeh, "Vocabulary Learning Strategies Used by Poor Iranian High School Students," International Journal of Language Teaching and Research vol. 2, pp. 12-15, 2014.

[21] M. J. Lawson and D. Hogben, "The Vocabulary-Learning Strategies of Foreign-Language Students "Language Learning vol. 46, pp. 101-135 1996.
[22] R. Kafipour, M. Yazdi, A. Soori, and N. Shokrpour, "Vocabulary levels and vocabulary learning strategies of Iranian undergraduate students," Studies in Literature and Language, vol. 3, p. 64, 2011.

[23] N. B. Subekti and M. J. Lawson, "Vocabulary Acquisition Strategies of Indonesian Postgraduate Students through Reading," International Education Journal, vol. 8, pp. 485-496, 2007.

[24] P. Bennett, "An Evaluation of Vocabulary Teaching in An Intensive Study Programme " Master of Arts Centre for English Language Studies Department of English University of Birmingham Birmingham, United Kingdom, 2006.

[25] I. S. P. Nation, Learning Vocabulary in Another Language. New York: Newbury House, 2001.

[26] Y. Gu and R. K. Johnson, "Vocabulary Learning Strategies and Language Learning Outcomes," Language Learning vol. 46, pp. 643-679 1996.

[27] E. B. Başoğlu and Ö. Akdemİr, "A Comparison of Undergraduate Students' English Vocabulary Learning: Using Mobile Phones and Flash Cards," The Turkish Online Journal of Educational Technology vol. 9 Issue 2010.

[28] B. Azabdaftari and M. A. Mozaheb, "Comparing vocabulary learning of EFL learners by using two different strategies: mobile learning vs. flashcards " The EUROCALL Review vol. 20, pp. 47-59, 2012.

[29] M. Lu, "Effectiveness of vocabulary learning via mobile phone," Journal of Computer Assisted Learning vol. 24, pp. 515-525, 2008.

[30] A. Rezvani and A. A. Jabbari, "The Effect of Teaching Different Vocabulary Learning Strategies on Reading Comprehension of Iranian EFL Learners " IOSR Journal Of Humanities And Social Science (IOSRJHSS) vol. 21, pp. 44-48 2016. 